HStud 24 (2010) 1, 21-39 DOI: 10.1556/HStud.24.2010.1.2

\title{
THE PRICE OF SURVIVAL: TRANSFORMATIONS IN ENVIRONMENTAL CONDITIONS AND SUBSISTENCE SYSTEMS IN HUNGARY IN THE AGE OF OTTOMAN OCCUPATION
}

\author{
LAJOS RÁCZ \\ Szeged University, Szeged \\ Hungary
}

\begin{abstract}
In the modern era the population of the Carpathian Basin, for political and environmental reasons, was bound to the fundamental alterations of the prevailing subsistence system. Over the course of the 16 th and the 17 th centuries the country became a borderland between the Habsburg and Ottoman Empires. The regional effects of the Little Ice Age were aggravated by the ravages of the warring armies. Moreover, the climate turned cooler and wetter, and in consequence marshlands and swamps grew significantly. The population of Hungary adapted to the nearly two centuries of warfare, the environmental effects, and the European economic environment by cultivating cattle breeding and exports. Cattle exports reached 250,000 at the end of the 16th century, and the country's economic unity survived intact in spite of the fact that Hungary itself had disintegrated politically. Following the close of the Turkish wars, Hungary became a part of the Central European Habsburg Empire.
\end{abstract}

Keywords: environmental history, Hungary, Ottoman occupation, subsistence systems, cattle trade, climate change, Little Ice Age

The period of Ottoman occupation (1541-1699) represents one of the most important turning points in Hungarian history. Before the Turkish invasion, the medieval Hungarian Kingdom had been a regional middle-power in Europe, and the artists of the Renaissance mentioned the city of Buda alongside Venice and Florence in the age of Matthias Corvinus (1458-1490). But with the incursion of the Ottoman armies, Hungary became a borderland, a frontline and bastion of Christianity for the 16th and 17th centuries. These two-hundred years represented an era of hardships for the population of Hungary, which was compelled to adapt, sometimes radically, to the changed circumstances. In this short study I review some of the transformations and adaptations of the subsistence systems of the Carpathian Basin during the Turkish wars. 


\section{The Area under Analysis}

The geographical and political units of the following environmental history analysis overlap to a large extent. The medieval Hungarian Kingdom occupied the whole Carpathian Basin, so I will use these two terms as synonyms. The Carpathian Basin spans some 325,000 square kilometers in the heart of Europe and forms the largest part of the Central European basin-area south and west of the Bohemian and the Viennese basin. The main geomorphologic feature of the area is its character as a basin. Two-thirds of the basin is below 500 meters above sea level, and half of it is below 200 meters, so it is a perfect plain. The climate of the Carpathian Basin is temperate. The yearly temperature average is around 10 degrees Celsius and precipitation is approximately $600 \mathrm{~mm}$ in the inner parts of the basin. There are four distinct historical geographical macro-regions in the Carpathian Basin: Transdanubia, the Highlands (present-day Slovakia), the Great Hungarian Plain, and Transylvania (part of Romania since 1918).

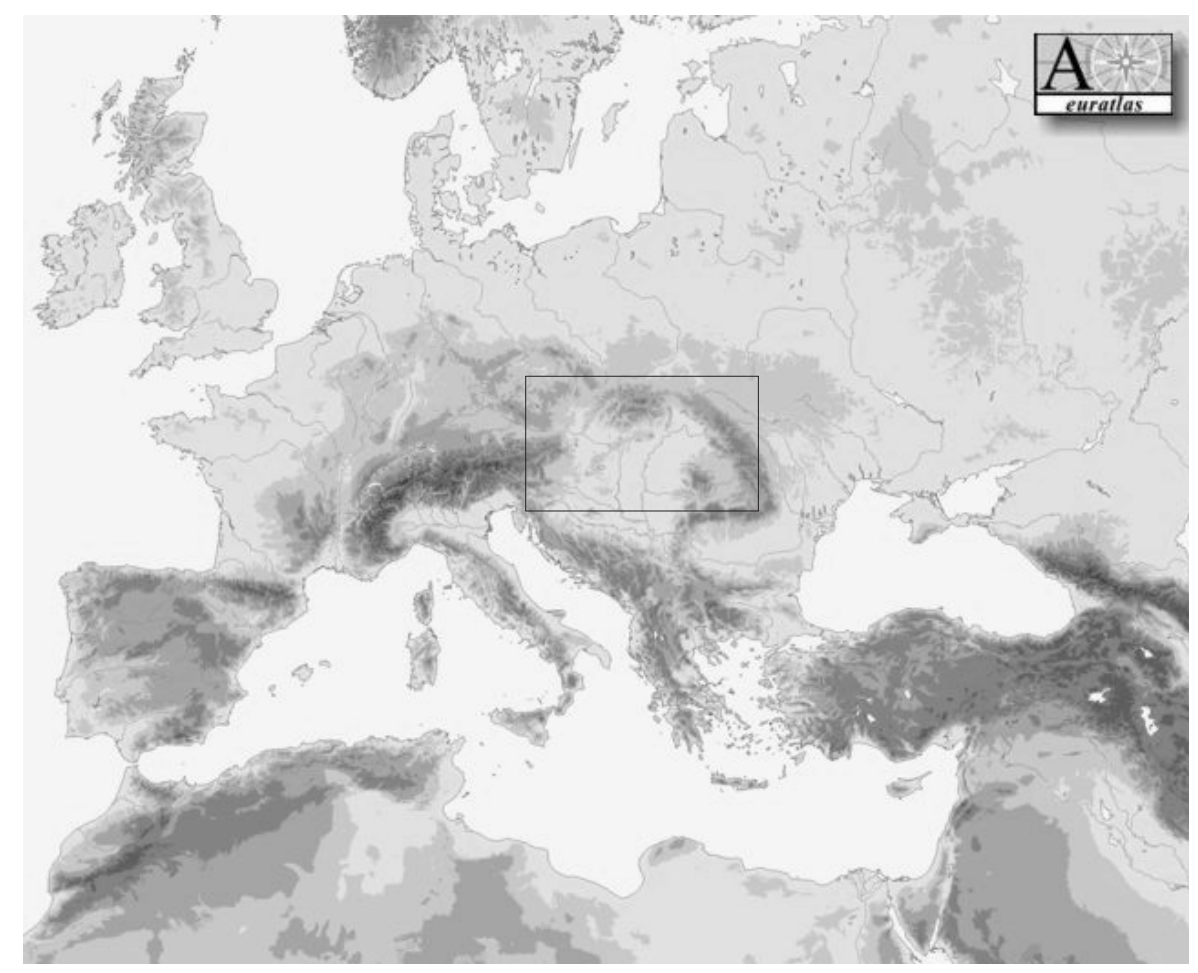

Figure 1. The Carpathian Basin in Europe 


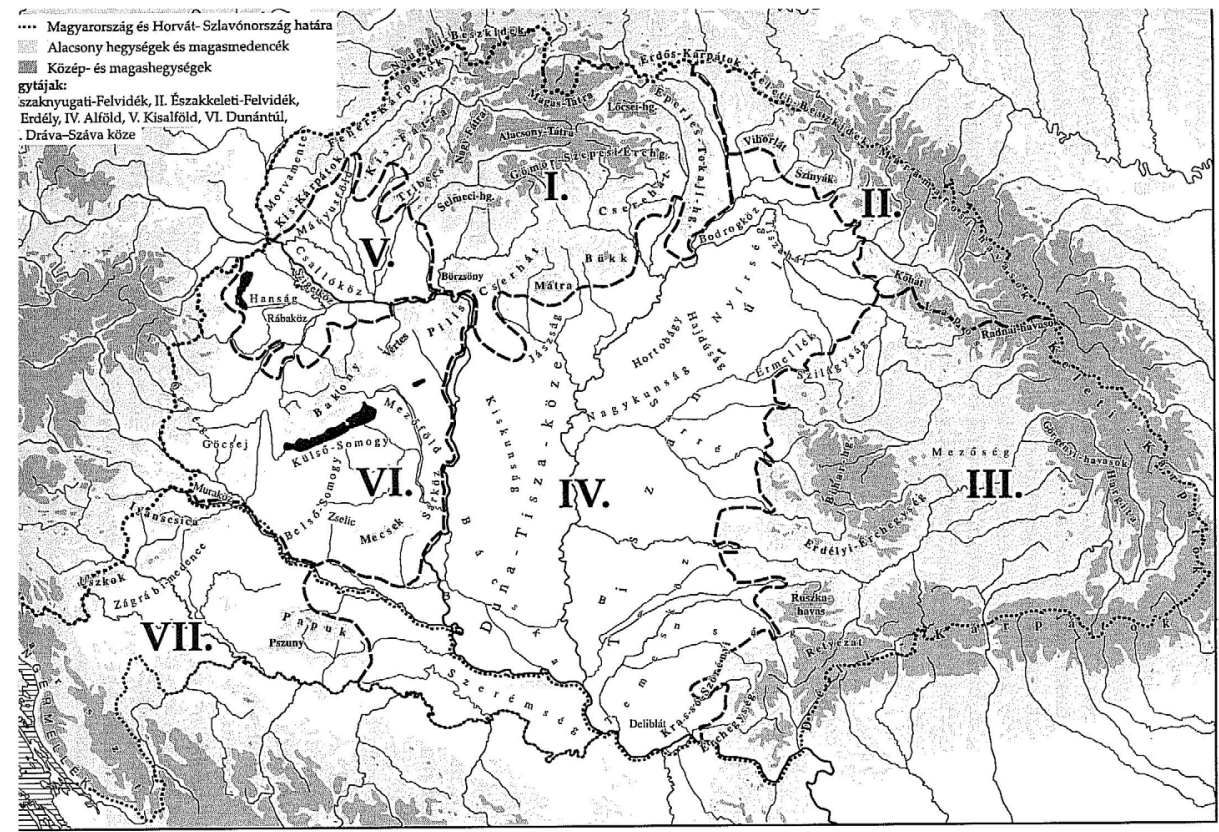

Figure 2. Historical regions of the Carpathian Basin

I. The Northern Highlands (today part of Slovakia), II. The Northeastern Highlands (today part of Slovakia and the Ukraine), III. Transylvania (today part of Romania), IV. The Great Hungarian Plain (the southern part of which is in present-day Serbia), V. The Small Hungarian Plain (the northern part of which is in present-day Slovakia), VI. Transdanubia, VII. Croatia.

\section{Political and Military Blows: The Turkish Invasion}

The Ottoman Empire arrived in the region of the medieval Hungarian Kingdom after the defeat of the Balkan coalition on the battlefield of Kosovo in 1389. The 15th century was an age of struggle between equal forces along the southern line of defense in Hungary. But during the first half of the 16th century the Turks delivered three decisive defeats to the Hungarian armies. On August 29th, 1521, following a long siege, the young Suleiman the Magnificent (1520-1566) captured the fort of Belgrade, which was the key fortress of the southern line of defense, leaving the Hungarian Kingdom indefensible. On August 29th, 1526 the royal Hungarian army suffered defeat at the hands of Suleiman in the battle of Mohács. The most tragic event of the battle took place in the last phase of the struggle, when the young Hungarian king, Louis II Jagiellon (1516-1526), died (the circumstances of his death were never clarified and became the source of numerous legends). In the wake of his fall, two candidates appeared for the crown: Ferdinand Habsburg (1526-1564) of Austria, the younger brother of Emperor 
Charles V, and János Zápolya (1526-1540), governor of Transylvania, whose forces never arrived at the battlefield of Mohács, thereby leaving him with the largest standing army in Hungary. Moreover, in all probability he was grandson of János Hunyadi (1407-1456), the former governor of Hungary. The Turkish army left the country in 1526, though soldiers remained in the key forts of the southern part of the country. During the fifteen year struggle over succession (1526-1541) the foreign policy of the Ottoman Empire was to support the weaker candidate, János Zápolya, and postpone the resolution of the feud, which dissipated the forces of the country. Finally, on August 29th, 1541 the janissary troops captured the fortress of Buda. The capital of the medieval Hungarian Kingdom became a Turkish border fort and the southern and central parts of the country were integrated into the Ottoman Empire for the next 150 years. Western Transdanubia, Croatia and the Highlands remained under Habsburg rule as Royal Hungary. The Transylvanian Principality became a satellite state of the Ottoman Empire, enjoying very limited and sometimes strictly controlled independence. Until the end of the wars fought between the Habsburgs and the Ottoman Empire over control of the former kingdom (1683-1699) the entire territory of Hungary was temporarily or continuously a battleground, which left the country in ruins.

\section{Environmental Blows: The Little Ice Age}

According to the consensus among climate historians the Little Ice Age began in the second third of the 14th century, after the close of the medieval warm epoch (9th-14th centuries), and came to an end in the last decade of 19th century (followed now by the recently acknowledged trend in global warming). During the Little Ice Age the global climate became cooler, but there were four specific periods of change in the process of climate decline: the middle of the 14th century, the last decades of the 16th century, the turn of the 17th and 18th centuries, and the first half of the 19th century.

There is no virtual documentary data concerning the climate history of the Carpathian Basin of the late Middle Ages. We can begin to reconstruct the climate history of Hungary beginning with the end of the 16th century, and the reliability of the model begins to increase considerably following the middle of the 17th century.

The climate of the Carpathian Basin followed the main trends of the European climate changes of the Little Ice Age, but we can identify two important regional features. First, precipitation was a more important indicator of climate changes in Hungary than temperature. When the European (and global) climate became cooler the quantity of precipitation increased in the Carpathian Basin while during the age of warming (as has happened recently), the climate became drier. Sec- 
ondly, during the periods of climate change the structure of the natural seasons in Hungary shifted. Natural seasons never coincide exactly with the seasons of the calendar, but these shifts were continuous and significant. During the specific periods of climate change of the Little Ice Age (the turn of the 17th and 18th centuries and the second third of the 19th century) winters became much longer. The month of March became a winter month and often the Danube remained under ice cover until the end of the first official spring month. The shift in the seasons gave rise to short, late summers limited to the months of July and August, resembling summers in Scandinavia. During the (recent) period of global warming the structure of natural seasons has simplified and the climate has become one marked by only two seasons, the winter, lasting roughly half of the year, and the summer, lasting the other half.

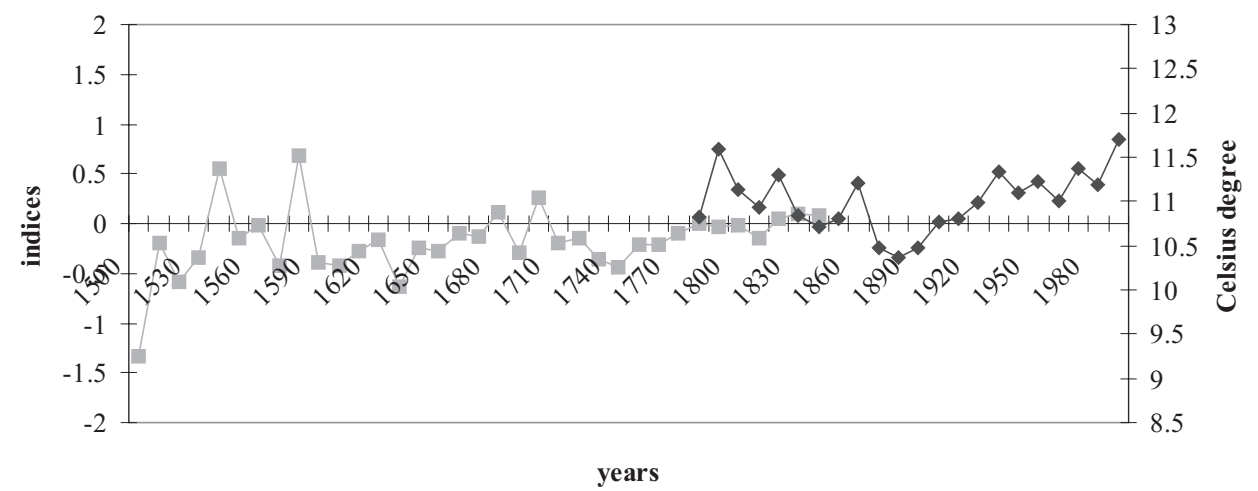

Figure 3. Temperature changes in the Carpathian Basin from the 16th century to the end of the 20th century, 10 year averages

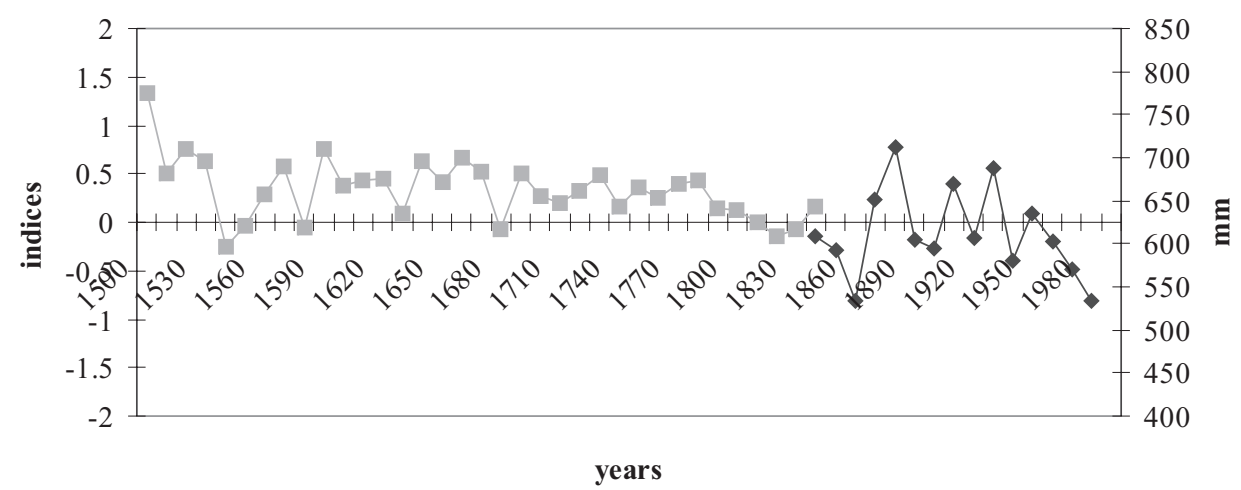

Figure 4. Temperature changes in the Carpathian Basin from the 16th century to the end of the 20th century, 10 year averages 
To summarize, the primary distinctive regional climate features of the Little Ice Age in the Carpathian Basin were the increasing level of precipitation and at the same time the increasingly long winter and ever shorter summer, though there were, within this dominant trend, colder and warmer and drier and wetter periods as well.

\section{Consequences of the Political and Environmental Blows}

\section{Reduction of Forest Area}

In the age of the Turkish wars the extent of forested land decreased considerably. This was due, above all, to the military use of timber. Building and reconstruction of forts, construction of ships for Hungarian and Turkish fleets, mining and metallurgy, canon founding and gunpowder preparation required a great quantity of wood. After the collapse of the southern line of defense of the Hungarian Kingdom the frontline of the war shifted to the central belt of the Carpathian Basin, where there was a shortage of stone. The armies therefore had to adopt a new approach to the construction of fortresses, called "plank-forts". "Plank-forts"

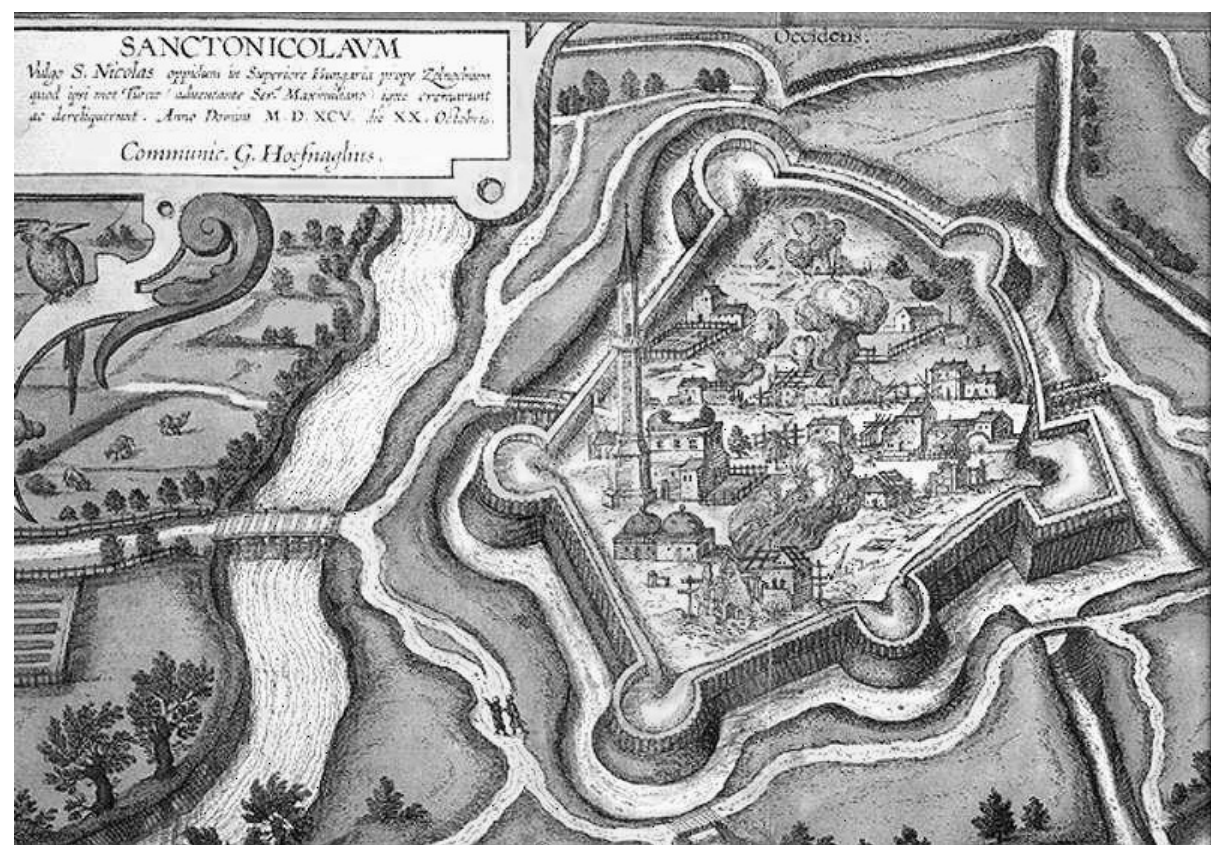

Figure 5. A plank fort: The fort of Törökszentmiklós (in the Great Hungarian Plain) in the era of the Turkish wars 
weren't an archaic or primitive form of fortress, but rather were in use anywhere where there was a shortage of stone. The same type of forts was built in the Netherlands during the Eighty Year War (1568-1648). Over the course of the 150 years of Turkish rule in Hungary only one stone fort was constructed, in Érsekújvár (Nové Zamky); all others were "plank-forts". Sometimes medieval castles and forts were rebuilt and completed with planks. The length of the frontline was between 400 and 500 kilometers, along which two lines of forts (Hungarian and Turkish) were constructed, primarily of oak, and with each passing decade the walls and roofs of the forts had to be rebuilt.

Quantitative data are available concerning the war industry's demand for timber. The gunpowder mill of Buda used between 600 and 1,600 tons of timber to prepare somewhere between 55 and 160 tons of gunpowder a year, but in addition to this mill six or seven others worked with a similar production capacity. The consumption of firewood in the forts was remarkable. According to the notes of the Hungarian Chamber, in the winter of 1674 the Hungarian forts of the Highlands alone burnt 24,542 coaches of firewood. On the basis of this statistic, one can conclude that the Hungarian and Turkish forts used some 100,000 coaches of firewood each winter. But one should note that in some areas of Hungary depopulation and the devastation of the village network extended the area of bush and woodland.

\section{The Extent of the Territories Covered by Water}

Before any climate changes took place, some 24,000 to 25,000 square kilometers of the Carpathian Basin were temporarily or continuously covered by water. These wet areas surely grew in early modern times for reasons of climatic change and as consequences of military actions. One of the most important regional features of the Little Ice Age was the longer autumn and the increase in precipitation. The rise in the water levels of Lake Balaton represents a clear indication of a significant precipitation surplus. Researchers are split in their assessments of the extent of changing water levels in early modern times, but the majority of the estimates suggest a rise of somewhere between three and five meters. At the end of the 17th century the Peninsula of Tihany was surely an island.

Interestingly, the increase of marshland was part of a general strategy of defense in the age of the wars with the Ottoman Empire. It was adopted primarily in the Great Hungarian Plain, where marshlands were used to improve the defensibility of forts. Marshlands were extended to provide an additional line of defense for the forts of Györ in the Small Hungarian Plain, Szolnok, Gyula, Temesvár, Szigetvár and Ecsed. In the case of Ecsed, for example, archaeological 
reconstruction has identified the sites of nine medieval villages in the marshland areas which were not swampland before the 16th century.

The depopulation of the central belt of the Carpathian Basin contributed to the extension of swampland. Inhabitants of medieval villages controlled the dense network of watercourses of the central belt of the Carpathian Basin with the help of a carefully controlled water regulation system of canals, flood-gates and reservoirs. Because of the devastation of the village network, the system of water regulation also collapsed, and without human intervention the marshes grew.

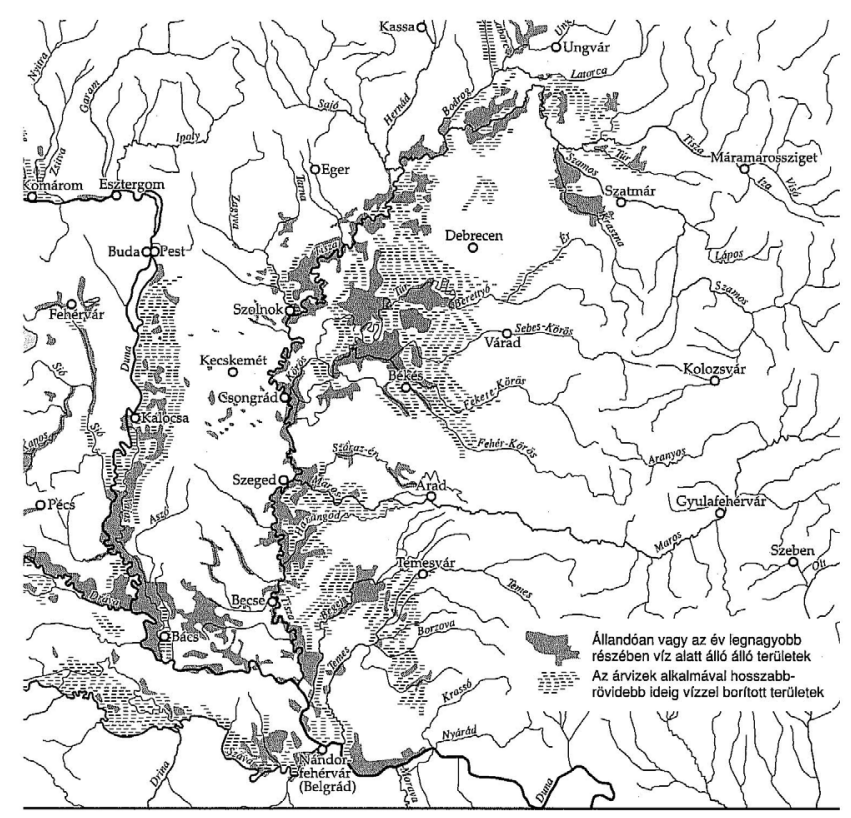

Figure 6. Areas of the Carpathian Basin continuously or temporarily covered by water

\section{Demographic Losses and Changes in Population Density in Hungary}

The Turkish invasion and expansion transformed the population density of settlements in Hungary during the late Middle Ages and early modern era. Until the last third of the 15th century the southern part of the Great Hungarian Plain was the population center of the medieval Hungarian Kingdom, in part because of the fertile soil and in part because of the high productivity of the vineyards of the area (known as Szerémség). Because of the continuous Turkish threat the population of the southern borderland of Hungary decreased. After the capture of Buda and the conquering of the southern and central parts of Hungary the Ottoman Empire 
integrated these regions into its administrative system. The settlement network and the settled population survived the first decades of Turkish occupation with minimal losses. Historical demographers estimate the population of the Hungarian Kingdom at 3.5 million at the beginning of 16th century. By 1580 the population had grown to an estimated 3.7 million, despite the military campaigns. Thus the population of the Carpathian Basin increased slightly, in spite of the devastation of the wars.

The first phase of the collapse of the settlement network took place in the period of the Fifteen Year War (1591-1606), when the high command of the Habsburg Empire attempted for the first time to expel the Turkish troops from Hungary, a venture in which they were unsuccessful. The human price of continuous warfare was the devastation of $20 \%$ of the population and the destruction of the village network in the Great Hungarian Plain and the eastern part of Transdanubia. Towards the end of the wars (1683-1699) the Hungarian Plain had lost $80-90 \%$ of its settlements and population. The loss was slightly lower in the Transdanubian borderlands.

At the turn of the 17th and 18th centuries the population of the Carpathian Basin reached 4,000,000, but the distribution and the density of the population changed a great deal during the age of the wars with the Ottoman Empire. The western and northern margins of the Carpathian Basin had the highest population density, with numbers comparable to other Central European countries. The mountainous Transylvanian Principality had the second highest population density, followed by the Great Hungarian Plain, which was a real demographic vacuum, with a population density between 1 and 5 persons per square kilometer.

\section{Forms of Adaptation}

The double effects of the continuous threats of military campaigns and environmental deterioration constituted a serious challenge for the peoples of the time throughout the Carpathian Basin, but the chance of survival was lowest in the area of the Great Hungarian Plain, where only some two dozen market towns managed to survive.

\section{Market Towns in the Great Hungarian Plain}

The Great Hungarian Plain (which should be distinguished from the Small Hungarian Plain in the northwest part of Hungary) is the largest macro-region of the Carpathian Basin, spanning some 100,000 square kilometers. During the Mid-

dle Ages a dense village network developed similar to the networks in other re- 


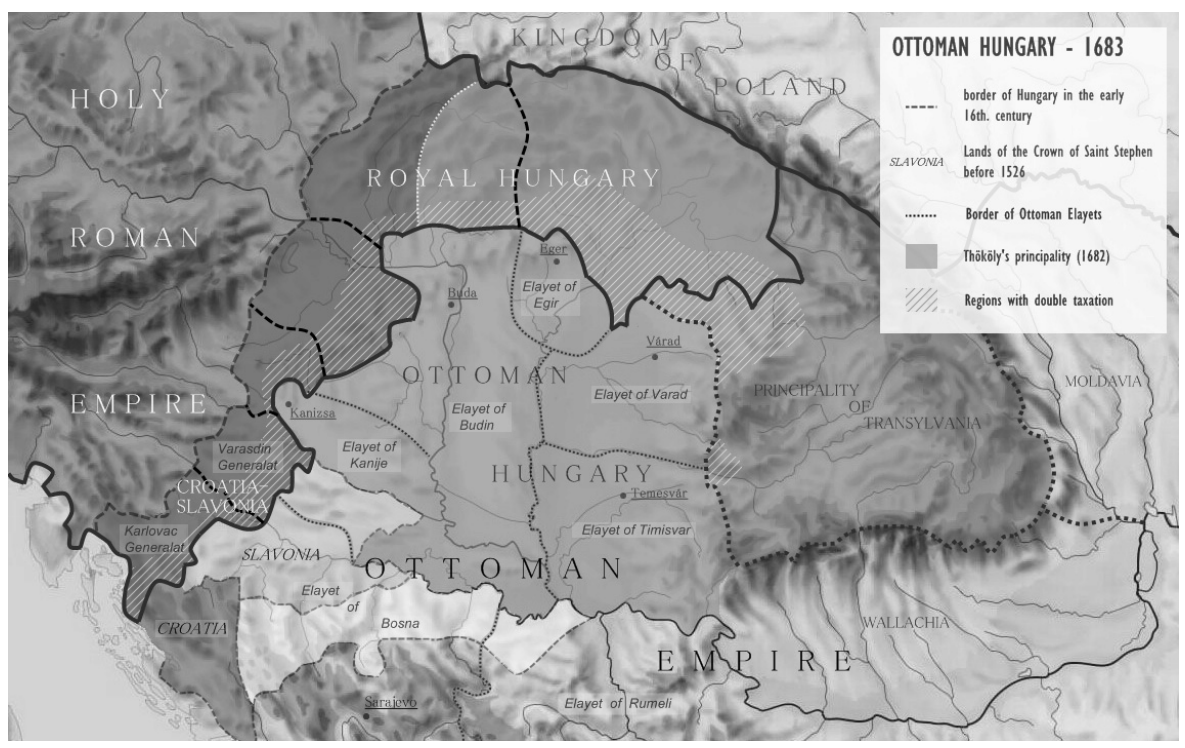

Figure 7. A country broken into three parts

gions of Hungary, but significantly, and unlike in the other regions of Hungary, in the Great Hungarian Plain the process of urbanization produced only one royal city (civitas), Szeged. Other urban settlements only gained status of market towns (oppidum). The explanation for this lies in the special structure of the medieval

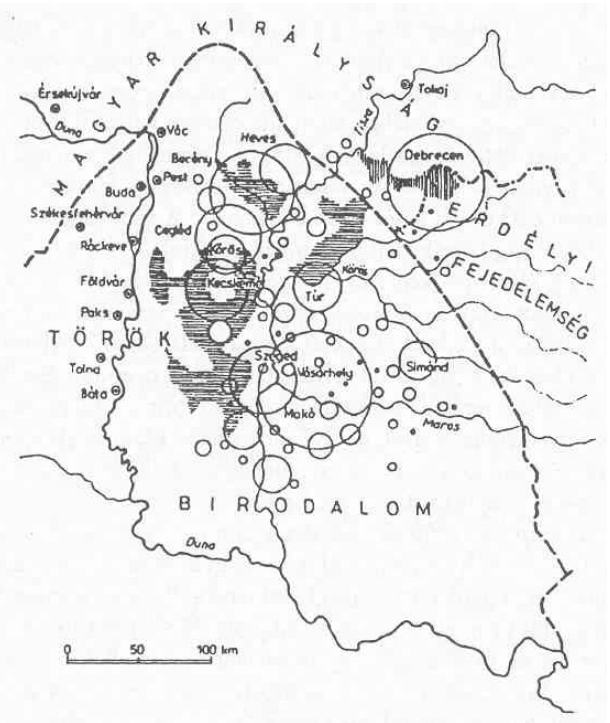

Figure 8. Market towns and their market districts in the age of the Turkish wars 
Hungarian economy, which was dominated by mining of precious metals and foreign trade of ores and other raw materials. The majority of royal cities (civitas) were therefore situated in mountainous areas and near the borderlands. Since the 14th century the market towns of the Great Hungarian Plain had specialized, in addition to the organization of local trade, in the interregional and international cattle trade. The main international markets of the Hungarian cattle trade were the northern Italian cities (Venice), cities of the Vienna Basin, Moravia and Bohemia, and cities of southern Germany (Augsburg and Nurnberg). During the late Middle Ages the tendency of settlement desertification reached the village network of the Great Hungarian Plain. The density of the village network decreased, partly because of waves of emigration to peripheral zones of the Carpathian Basin (which promised tax free settler status) and partly because of immigration to the market towns, which offered jobs for newcomers in connection with the cattle trade.

\section{Borderline Effects}

Following the Turkish occupation the frontline moved to the northern boundaries of the Great Hungarian Plain, and this macro-region officially became the a part of the Ottoman Empire, though the Hungarian landlords regularly appeared under the protection of soldiers of Hungarian forts and collected their seigneurial taxes from their (former) serfs. The occupied counties therefore became an area of double taxation.

The Turkish administration introduced two forms of ownership and exploitation to the conquered lands. The market-towns became the property of the Sultan and their taxes and tributes were paid directly to the central treasury. The direct connection to the central administration assured special status and for the most part saved the market towns from the ravages of Turkish troops. Villages also became the property of the Sultan, because all property of the Empire was the property of the Emperor, and each man was the slave of the Sultan, but the Sultan distributed these estates among Turkish landlords, called Spahis (light cavalry in the Turkish army). The Spahis had only temporary use of these estates, so they sought to squeeze wealth from the land as quickly as possible. Both exploitation by Turkish landlords and double taxation contributed to the destruction of the village networks and prompted people to resettle in the market towns. The village, as a form of settlement, disappeared from the Great Hungarian Plain, except in some peripheral areas where the physical environment (primarily marshland) allowed them to survive. 


\section{Shelter for Refugees}

Market towns had been destinations for large groups of people migrating from villages since the 14th century, but immigration increased in the 16th century, partly because of the wars with the Turks and partly because of the great boom in the cattle trade with the highly urbanized centers of Northern Italy and Central Europe. Generally immigration was an individual decision, but because of the aggravations of warfare sometimes whole village communities moved to the market towns under the direction of magistrates and offered their territories to the towns as tenements. As a result of the periodic waves of refugees, the population of the market-towns of the Great Hungarian Plain increased quickly. In the middle of the 17 th century Debrecen became the largest urban settlement of the Carpathian Basin with, 15,000 inhabitants. The population of the second line of market towns (Kecskemét, Cegléd, Nagykörös) exceeded 5,000 and was equal to that of the cities of Royal Hungary. But the increase in population (and the great benefit of cattle trade) was not accompanied by reconstruction of the infrastructure. Contemporary pictures and archaeological reconstructions indicate that the villages "flowed" into the towns, and the market towns tended to resemble giant villages. Debrecen, the largest urban settlement of Hungary, had less than ten buildings made of stone at the beginning of 18th century. At the time István Dobozi, the mayor of Debrecen, lived in a simple clay-walled peasant house (a kitchen and two rooms) with his wife and three sons. This was not a sign of poverty, neither for the town nor for the family of the mayor, but during the period of continuous warfare, in which the threat of plundering troops always lingered, forms of investment had had to be chosen carefully. Debrecen was undoubtedly one of the main market centers of the Great Hungarian Plain and the whole Carpathian Basin not to have representative buildings, and the mayor's family had more than 1,000 cattle grazing on the fields of Hortobágy. The early Modern Era was an age of spectacular reconstruction for the towns of Central Europe. In Moravia, Bohemia and Austria, given the relative security and steady pace of public life, it was worth investing in the construction of buildings, mansions and palaces. But until the end of the Turkish wars the people of Hungary invested rather in animal husbandry and precious metals, which could be easily hidden from plundering soldiers.

\section{The Cattle Trade: Connections with (Central) Europe}

The origin of the cattle trade between Hungary and the urbanized centers of Central Europe can be traced back to the beginning of the 14th century. Medieval demographic growth led to a high demand for the staple foods of European pe-

ripheries, and a large food export zone came into being stretching from Poland to 
Hungary. Given the high costs of ground transport, the continental countries were able to export only beef overland. The main staple of Hungarian animal export was the mysterious Hungarian grey cattle. There is no reliable data concerning the origin of this species, because the earliest archaeological evidence dates only to the 16th century. Two theories offer explanations of the origins of the grey cattle. According to the first, the species derives from a crossing with the wild bullock. According to the second, it arrived in the Carpathian Basin in the 13th century with Cuman tribes from the steppes of Eastern Europe. But there is neither documentary nor archaeological evidence to support either of these theories. One nonetheless can suppose that the grey cattle were the main staple of the Hungarian cattle trade since the late Middle Ages. The grey cattle were ideal for long distance trade. The species can endure long periods of roving and can subsist on pasturelands for more than a year without stabling, and its meat is delicious.

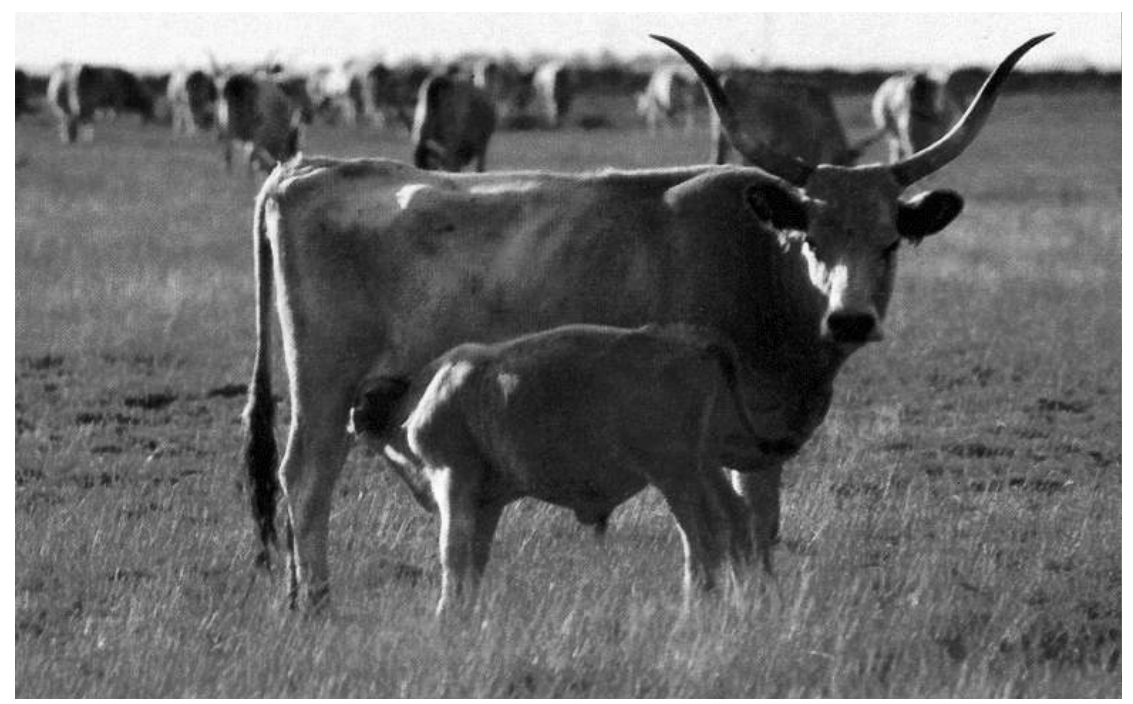

Figure 9. The staple of the cattle trade: The Hungarian grey cattle

As a consequence of the subsistence crises of the 14th century the demand for the foodstuffs of the eastern territories dropped, but the temporary decline in trade never brought an end to the commercial connections. Therefore, when at the beginning of the 16th century the European population reached the levels of the period before the age of the Black Death, demand for the foodstuff surpluses of Eastern Central Europe again increased and revitalized the former connections. The 16th century was a golden age of the Hungarian cattle trade. In the second half of the 16th century 200,000 cattle were exported every year, and in some years a little bit more. The organization of the cattle trade with large areas of production, the 
maintenance of the dense network of droving routes and rented grazing lands, and the negotiation of agreements with leaders of different administrations in the areas plagued by warfare were complex but profitable undertakings. One should consider three aspects of the Hungarian cattle trade: production areas, organizers of and laborers in the cattle trade, and the uses to which profits were put.

\section{Cattle Breeding Areas}

The main cattle breeding area was the Great Hungarian Plain. The Plain was home to an old tradition of animal husbandry dating back to the high Middle Ages, but in the age of the Turkish wars the political and military conditions became ideal for cattle husbandry. As a consequence of the long period of warfare the village network collapsed, the large grain fields disappeared, and animal husbandry represented the single remaining possibility for economic use of the large, unpopulated areas. The market towns of the Great Hungarian Plain, which were centers and organizers of the cattle trade, developed a special settlement morphology and economy to maximize the efficiency of the town economy and animal husbandry. This innovation of market towns is referred to as the "pen garden system", in which there were six separate zones of economic activity. The core area was the dwelling zone, which had a small courtyard, enough only for the building site and poultry. The second was the pen garden zone, where the young adult men lived, keeping the useful animals and beasts of burden in pens (milk-cows, drawing cows and horses, saddle-horses) and storing grain, straw, and hay. This second dwelling zone was extremely dangerous for young women, mainly after dark. The next three economic zones followed the same structure of the zones in other towns

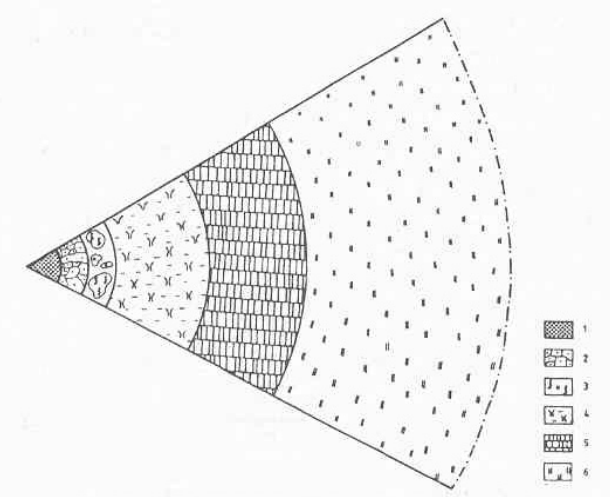

Figure 10. The model of pen garden farming: 1. dwelling zone, 2. pen garden, 3. garden zone, 4. inner grazing land, 5. arable land, 6. external grazing land 
in Hungary: the garden zone (for growing fruits, vegetables, and grapes), grazing land (for milk cows and beasts of burden), and arable land. The most important innovation in the market towns of the Great Hungarian Plain was the high flexibility of external grazing lands. The external grazing lands were able to integrate territories of devastated villages with techniques of tenement or with simple occupation of lands in disuse.

The outskirts of market towns can grow dramatically. The outskirts of Debrecen, for example, were a little bit larger than 170,000 hectares and the territories of Kecskemét and Nagykörös changed by about 250,000 to 300,000 hectares. But from the second line of market towns, Jászberény managed its animal husbandry on some 60,000 hectares. The majority of these large territories were outside grazing land, in areas where cattle were raised.

The Great Hungarian Plain was the primary but not exclusive area of cattle breeding. Cattle breeding areas of Transylvania, Moldova, Walachia and the northern provinces of the Balkan Peninsula were integrated into the cattle industry of the Plain. So the Carpathian Basin (the geographical framework of the medieval Hungarian Kingdom) became a divided political space for expansion of the Ottoman Empire, but through the early modern recovery of the cattle trade the Carpathian Basin saved its economic unity. Moreover, it integrated substantial surrounding areas into the (Central) European market.

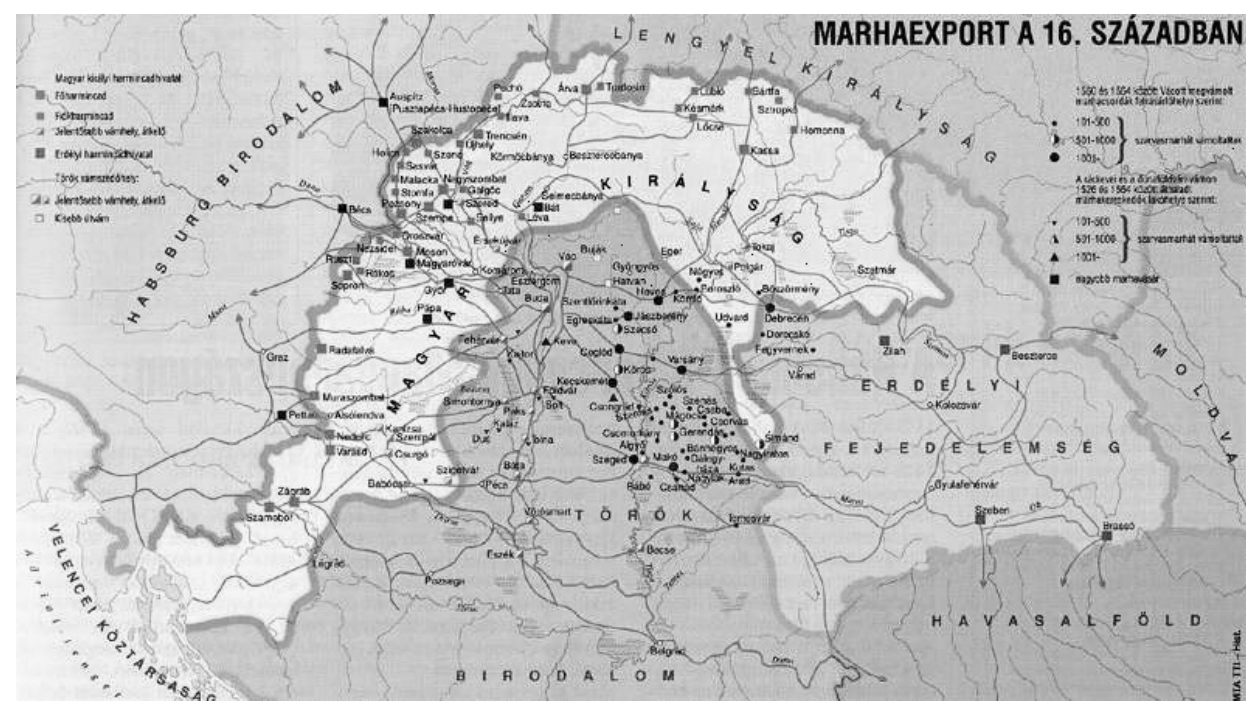

Figure 11. Cattle drover roads in the Carpathian Basin in the 16th century 


\section{Organizers, Agents and Labourers of the Cattle Trade}

Organizing the route of a calf from the grazing lands of Hortobágy to the cities of Nurnberg, Venice or Vienna was not a simple logistic problem during times of peace, but during times of war risks and expenses increased. Experts in this profession emerged from the social class of traders and shepherds

Cattle traders came to form a special group of the Hungarian bourgeoisie. The majority hailed from market towns, and as far as their social status was concerned they were serfs like other dwellers of market towns. But despite their low position in the social hierarchy they were one of the richest strata of Hungarian society, and they frequently used their wealth to buy noble titles, thereby ascending into the ranks of the lower nobility. Imre Thököly, a descendant of a cattle trader dynasty, became ruler of Hungary in the final troubled decades of the wars with the Ottoman Turks (1683-99). His father, Sebestyén Thököly, had been a lowborn horse and cattle drover, yet he had received a baronial title in exchange for loans provided to the Habsburg court.

The market towns were centers for protestant churches, and the majority of the cattle traders were protestant. The Turkish administration saved the population of the occupied provinces from the efforts of the Counter Reformation. The reformed churches, primarily Calvinist, were therefore able to organize local administration and elementary and secondary schools. Pastors of the reformed church studied at universities in southern Germany, of which Wittenberg and Heidelberg were the most popular, and in the Netherlands at the University of Leiden. Protestant theologians often travelled to the Holy Land, which at the time was part of the Ottoman Empire, to study religious texts. The opinions of contemporaries, who as early as the 17 th century referred to the market town of Debrecen as "Calvinist Rome," testify to the strength of the protestant church in Hungary.

The most important competitors of the serf or bourgeois cattle traders were the prominent families of the Hungarian nobility, the Perényi, Nádasdy and Zrínyi families. The profits to be made in the cattle trade prompted them to lay aside their prejudices against the profession. For noble traders cattle trade offered numerous advantages in commerce, including immunity from direct taxation and some from duties, a steady position in the civil and military administration of Royal Hungary,

and last but not least armed escort. It was not coincidental that in the territory of Royal Hungary these noblemen crowded the serf and bourgeois competitors from the cattle trade, but the occupied provinces were beyond their sphere of direct influence. The Catholic faith of noble traders lent a special religious flavor to this commercial and social competition.

Without the collaboration of Turkish officers it was not possible to organize the cattle trade across the areas of combat and the frontlines. Turkish constables 


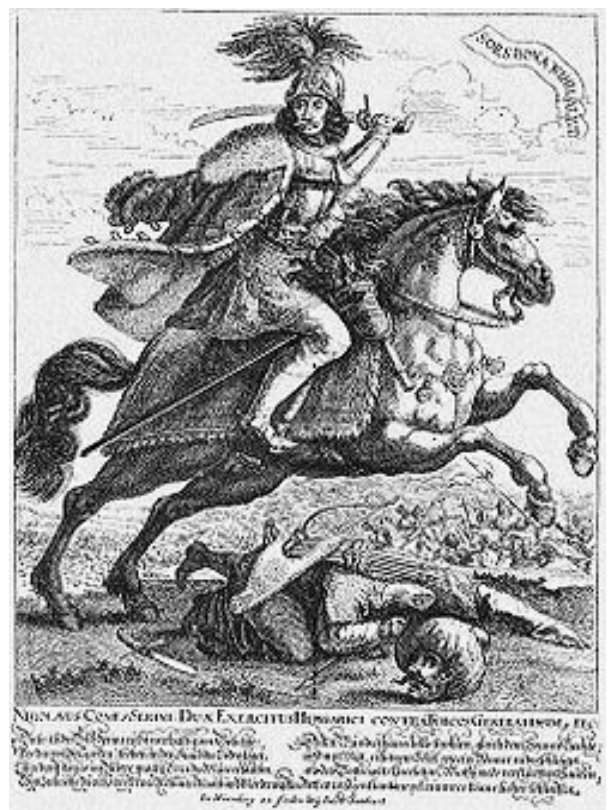

Figure 12. Miklós Zrínyi (1620-64, Nikola Zrinski), strategist, politician and businessman

and officers received a portion of the profits and in exchange supported the droving paths and boundary crossing stations with their military forces. Turkish officers very frequently collaborated with Hungarian constables to coordinate the cattle trade and organize fairs of the regional trade to augment their incomes. Moreover, the majority of Turkish officers were not Turks, but renegades from Balkan countries who knew the regional connections of the Carpathian Basin well.

Droving cattle herds from the grazing lands of the Great Hungarian Plain to the far markets of Central Europe and Northern Italy was a hard and dangerous job. A special group of experts formed known as the Heyducks. The majority of Heyducks rose from peasant society, leaving their village communities and escaping their status as serfs. Given their rootless social status and lifestyle, they were similar to the Cossacks in Russian society. Like the Cossacks, the Heyducks were members of a semi-military social group who sold their services in the military market as mercenaries as well. There were a lot of legends about the cruelty of Heyducks, and according to general opinion they were crueler than Turkish soldiers. In the case of Nurnberg, the authorities constructed pubs for Heyducks outside of the city walls at the expense of the magistrate to avoid conflicts with locals. They also prohibited the Heyducks from entering the city. 


\section{The Price of Survival}

The 16th century saw a recovery of agrarian prices in Europe, which assured high profits for producers. But the profits of the cattle trade swallowed the expenses of long and unremitting warfare.

The noblemen officers of the Habsburg army financed the salaries of soldiers and the expenses of the reconstruction of forts partly from their commercial incomes. This was due neither exclusively to altruism nor to patriotism, but rather to the fact that these forts frequently safeguarded the estates of constables. The landlords who had escaped from occupied territories often found themselves impoverished and deprived of their privileged social status. The princes and counts of Hungary spent the rest of the profits from the cattle trade on luxury articles (spices, jewels, expensive clothes, and arms) and the construction of fortified residences, in accordance with the general practice of early modern European nobility.

The cattle traders of the market towns spent money on luxury goods, but they showed greater restraint and moderation, perhaps in part because of their protestant faith. Two of the primary benefits of the trade were reinvestment in livestock and the creation of some wealth removed from commercial cycles as personal fortune. But these fortunes were tapped by tax officers and landlords of the two empires and filched by plundering soldiers of the regular and irregular armies, and the cattle traders had to calculate with a hostile natural environment which took its toll from time to time.

At the beginning of 17 th century there was a radical drop in the demand for the (Central) European foodstuffs. By the middle of 17th century the export of Hungarian livestock had fallen from somewhere between 200,000 and 250,000 at its peak to somewhere between 50,000 and 60,000, and the struggle over the shrinking market became increasingly intense. Towards the end of 17 th century the era of Ottoman occupation came to a close, and with it the golden and even silver ages of the cattle trade as well. Hungary integrated into the framework of the Central European Habsburg Empire, and the country was compelled to find its place in a larger political and economic configuration. New answers and new forms of subsistence systems had to be formulated to address the new challenges. The age of the market towns of the Great Hungarian Plain, the "pen garden system," and mass cattle trade came to an end, but with the help of this subsistence system the inhabitants of the Carpathian Basin proved able to pay the price of survival. 


\section{References}

Bartosiewicz, László (2003) 'People and Animals: The Archaeozoologist's Perspective' in József Laszlovszky-Péter Szabó (eds) People and Nature in Historical Perspective (Budapest).

Beluszky, Pál (2001) A Nagyalföld történeti földrajza (Historical Geography of the Great Hungarian Plain) (Budapest-Pécs).

Frisnyák, Sándor (1999) Magyarország történeti földrajza (Historical Geography of Hungary) (Budapest).

Glaser, Rüdiger (2001) Klimageschichte Mitteleuropas. 1000 Jahre Wetter, Klima, Katastrophen (Darmstadt).

Pfister, Christian (1999) Wetternachhersage. 500 Jahre Klimavariationen und Naturkatastrophen (Bern).

Rácz, Lajos (1999) Climate History of Hungary since 16th Century: Past, Present and Future (Pécs).

Rácz, Lajos (2001) Magyarország éghajlattörténete az újkor idején (Climate History of Hungary during the Modern Times) (Szeged).

Rácz, Lajos (2008) Magyarország környezettörténete az újkorig (Environmental History of Hungary Until the End of Modern Times) (Budapest).

Szabó, Péter (2003) 'Source for the Historian of Medieval Woodland' in József Laszlovszky-Péter Szabó (eds) People and Nature in Historical Perspective (Budapest). 